\title{
Cytotoxic and Antiviral Activities of Colombian Medicinal Plant Extracts of the Euphorbia genus
}

\author{
LA Betancur-Galvis $/{ }^{+}$, GE Morales*, JE Forero, J Roldan** \\ Grupo Inmunovirología-Biogénesis *Grupo GIEM **Departamento de Biología, Universidad de Antioquia, Apartado 1226 , \\ Medellín, Colombia
}

\begin{abstract}
Forty-seven plant extracts of 10 species of the genus Euphorbia (Euphorbiaceae) used by Colombian traditional healers for the treatment of ulcers, cancers, tumors, warts, and other diseases, were tested in vitro for their potential antitumour (antiproliferative and cytotoxic) and antiherpetic activity. To evaluate the capacity of the extracts to inhibit the lytic activity of herpes simplex virus type $2(\mathrm{HSV}-2)$ and the reduction of viability of infected or uninfected cell cultures, the end-point titration technique (EPTT) and the MTT [3-(4,5-dimethylthiazol-2-yl)2,5-diphenyltetrazolium bromide] colorimetric assay were used, respectively. The therapeutic index of the positive extracts for the antiviral activity was determined by calculating the ratio $C C_{50}(50 \%$ cytotoxic concentration) over $I C_{50}(50 \%$ inhibitory concentration of the viral effect). Five of the 47 extracts (11\%) representing 3 out of 10 Euphorbia species (30\%) exhibited antiherpetic action; the highest activity was found in the leaf/stem watermethanol extracts from $\mathrm{E}$. cotinifolia and $\mathrm{E}$. tirucalli. The therapeutic indexes of these two plant species were > 7.1; these extracts exhibited no cytotoxicity. Six extracts (13\%) representing 4 plant species (40\%) showed cytotoxic activity. The highest cytotoxicity was found in the dichloromethane extract obtained from $\mathrm{E}$. cotinifolia leaves and the $\mathrm{CC}_{50}$ values for the most susceptible cell lines, HEp-2 and CHO, were 35.1 and $18.1 \mu \mathrm{g} / \mathrm{ml}$, respectively.
\end{abstract}

Key words: Euphorbiaceae - ethnobotany - medicinal plants - antiviral - herpes simplex virus - Colombia

Several species of the genus Euphorbia (Euphorbiaceae) have been tested for their efficiency as antiviral and antitumour agents, partly based on information concerning plants that have traditionally been used as medication to treat various human diseases (Bernal \& Correa 1990, Unander et al. 1995). In fact, pronounced antiviral activity has been reported in several species of the genus Euphorbia, against polio, coxsackie, and rhinoviruses (Vlietinck et al. 1986, 1995, Ninomiya et al. 1990, Unander et al. 1995). Additionally, antitumour activity against sarcoma 180 ascites, leukemia in mice, and cytotoxic activity against certain cancer cell lines has also been observed (Itokawa et al. 1989, Wu et al. 1991, Fatope et al. 1996).

There seems to be increasing possibility of finding biological activity among plants with recorded medicinal uses rather than from plants randomly selected (Unander et al. 1995, Cordell 1995). Furthermore, selection of plants gives better criteria for screening programs especially in its initial phases, compared to the screening of compounds isolated and/or purified from natural products (Kusumoto et al. 1995, Cordell 1995, Baker et al. 1995).

Finally, the strategy for research and in vitro evaluation of biological activity of natural products, has changed in the past few years. One of the recent developments is the highly automated bioassay screening method based

This work received financial support from the University of Antioquia.

${ }^{+}$Corresponding author. Fax: +574-510.6062. E-mail: labeta@catios.udea.edu.co

Received 10 May 2001

Accepted 25 April 2002 on colorimetric assays, that quantify the proliferation of cell cultures (Mosmann 1983, Denizot \& Lang 1986). These techniques, considered rapid and inexpensive for the evaluation of antitumour (Carmichael et al. 1987, Rubinstein et al. 1990) and antiviral activity (Weislow et al. 1989) of a large number of natural products, have also permitted the isolation and purification of biologically active principles (Cordell 1995, Baker et al. 1995).

The objective of our work was to evaluate, using colorimetric assays, the in vitro antiherpetic and cytotoxic activity of some Euphorbia species that are known in Colombia, to have traditional medical uses against skin infections such as ulcers, warts, cancers, tumors, and possibly diseases of viral origin (Garcia-Barriga 1974, Perez 1975, Vasquez 1982, Bernal \& Correa 1990, Piñeros et al. 1992).

\section{MATERIALS AND METHODS}

Plant collection - The species were collected in different municipalities of the Department of Antioquia and deposited in the herbarium of the University of Antioquia, Medellín, Colombia. E. cotinifolia, was collected in Girardota, at a mean altitude of $350 \mathrm{~m}$; a voucher specimen was deposited under the number HUA 115472. E. cestrifolia was collected in Guarne, at a mean altitude of 2,000 m; a voucher specimen was deposited under the number HUA 95065. E. tirucalli, E. arenaria, and E. pulcherrima were collected in Medellín, at a mean altitude of $450 \mathrm{~m}$; voucher specimens were deposited under the numbers RC11383, HUA 55275, RC11384, respectively. The species E. heterophyla, E. cyatophora, E. graminea, E. cf. cotinifolia and Euphorbia sp. were collected in San Jerónimo, at a mean altitude of $700 \mathrm{~m}$ and voucher specimens were deposited under the numbers HUA 88875, F.J. Roldán 2439, 2442, 2437, 2443, respectively. 
Extract preparation - $100 \mathrm{~g}$ of plant tissue obtained from the parts of the plants described in Table I were dried at $40^{\circ} \mathrm{C}$ for $8 \mathrm{~h}$. The powdered plant material was percolated sequentially with $500 \mathrm{ml}$ of the following solvents: petroleum ether, dichloromethane, ethanol, and water. Additionally, water-methanol (20:80) extracts of $E$. cotinifolia and E. tirucalli species were prepared from fresh green plants. The various extracts were carefully evaporated to dryness under reduced pressure and were stored at $-20^{\circ} \mathrm{C}$, until used. To test the biological activity, the dried crude extracts were dissolved in dimethyl sulfoxide (DMSO, Sigma) to a concentration of $250 \mathrm{mg} / \mathrm{ml}$, and at the time of assay two-fold dilutions were prepared in cell culture medium starting from a concentration of $1,000 \mu \mathrm{g} / \mathrm{ml}$ of extract.

Cell culture and virus - The cell lines used were Cricetulus griseus Chinese hamster ovary cells ( $\mathrm{CHO}$ cell line ATCC CCL-61), human cervix epitheloid carcinoma cells (HeLa cell line ATCC CCL-2), human larynx epidermoid carcinoma cells (HEp-2 cell line ATCC CCL23), and Cercopithecus aethiops African green monkey kidney cells (VERO cell line ATCC CCL-81). Bovine fibroblast primary culture cells of Bon criollo Colombian cattle (BonFib) were obtained in our laboratory from bovine ear skin biopsies. Briefly the protocol used to obtain primary cell cultures from the biopsy was as follows. Each biopsy was washed three times with Phosphate Buffered Saline (PBS) containing $200 \mathrm{units} / \mathrm{ml}$ of penicillin, $200 \mu \mathrm{g} / \mathrm{ml}$ of streptomycin and $0.5 \mu \mathrm{g} / \mathrm{ml}$ of amphotericin B. The skin was discarded, the cartilage and the subcutaneous tissue was minced finely, the pieces of tissue were placed in $25 \mathrm{~cm}^{2}$ cell culture flasks with just enough growth medium, i.e. Eagle minimum essential medium (MEM) with $2 \mathrm{mM} \mathrm{L-}$ glutamine, $1 \%$ vitamins, $1 \%$ non essential amino acids, $100 \mathrm{units} / \mathrm{ml}$ of penicillin, $100 \mu \mathrm{g} / \mathrm{ml}$ of streptomycin, 0.25 $\mu \mathrm{g} / \mathrm{ml}$ of amphotericin B, and $10 \%$ of fetal bovine serum (FBS) to cover the pieces of tissue. When the fibroblasts had proliferated to 30 or $40 \%$ confluence, the pieces of tissue were discarded by gently shaking with PBS, and again the cells were fed with $50 \%$ of used medium and $50 \%$ of fresh medium. When $80 \%$ confluence was reached, the cells were trypsinized and cultured in $150 \mathrm{~cm}^{2}$ flasks. Once the cells had covered about $80 \%$ of the surface, they were trypsinized, centrifuged and cryopreserved.

All cells were grown in MEM supplemented with $10 \% \mathrm{FBS}, 100 \mathrm{units} / \mathrm{ml}$ of penicillin, $100 \mu \mathrm{g} / \mathrm{ml}$ of streptomycin, $2 \mathrm{mM} \mathrm{L}$-glutamine, $0.07 \% \mathrm{NaHCO}_{3}$, and $1 \%$ nonessential amino acids and vitamin solution. The cultures were maintained at $37^{\circ} \mathrm{C}$ in humidified $5 \% \mathrm{CO}_{2}$ atmosphere.

Herpes simplex virus type 2 (HSV-2) was obtained from the Center for Disease Control (Atlanta, GA, USA). The virus stock was prepared from HSV-2-infected HEp-2 cell cultures. The infected cultures were subjected to three cycles of freezing-thawing, and centrifuged at 2,000 rpm for $10 \mathrm{~min}$. The supernatant was collected, titrated, and stored at $-170^{\circ} \mathrm{C}$ in $1 \mathrm{ml}$ aliquots. To titre the virus suspension, confluent monolayer Vero cells were grown in 96well flat-bottomed plates and were infected with $0.1 \mathrm{ml}$ of serial tenfold dilutions of the virus suspension by quadruplicated for a period of $48 \mathrm{~h}$. The virus titre was $10^{3.5}$ (the dilution of the virus required to $\mathrm{TCID}_{50 / 0.1 \mathrm{ml}}$ lytic effect $50 \%$ of the inoculated cultures) using the SpearmanKäber formula (Lorenz \& Bögel 1973).

Antiviral assays

End-point titration technique (EPTT) - The technique described by Vlietinck et al. (1995), with a few modifications, was used. Briefly, confluent monolayer Vero cells were grown in 96-well flat-bottomed plates. Two-fold dilutions of the extracts in maintenance medium, identical to growth medium except for FBS which was $2 \%$, were added $1 \mathrm{~h}$ before viral infection. Cells were infected with $0.1 \mathrm{ml}$ of serial ten-fold dilutions of the previously titrated virus suspension and incubated again at $37^{\circ} \mathrm{C}$ in humidified 5\% $\mathrm{CO}_{2}$ atmosphere for $48 \mathrm{~h}$. Controls consisted of infected cells with HSV-2 serial ten-fold dilutions in the absence of the extracts, treated noninfected and untreated noninfected cells. The antiviral activity is expressed as the maximal nontoxic dose of the test extract needed to obtain the reduction virus titer. The reduction in virus titer was determined as the reduction factor (RF) of the virus titer, i.e. the ratio of the virus titer in the absence over virus titer in the presence of the extract. Three assays were carried out in duplicate with at least 5 concentrations. The results are expressed as the mean obtained from 3 different assays. The extracts with RF values of $1 \times 10^{2}$ to $1 \times 10^{4}$ indicating a pronounced antiviral activity were selected for evaluation of the antiviral assay using the MTT (3-(4,5-dimethylthiazol-2-yl)-2,5-diphenyltetrazolium bromide) colorimetric technique.

\section{MTT assay}

Antiviral colorimetric assay - VERO cell monolayers were grown in 96-well microtiter plates. Dilutions of the extracts, prepared as described above for the EPTT assay, were added $1 \mathrm{~h}$ before viral infection. Ten infectious doses of virus were added to each well and incubated at $37^{\circ} \mathrm{C}$ in humidified $5 \% \mathrm{CO}_{2}$ atmosphere for $48 \mathrm{~h}$. Controls consisted of untreated infected, treated uninfected and untreated uninfected cells. Furthermore all tests were compared with a positive control, Acyclovir (Quiviral, Laboratorios Quibi, Santafé de Bogotá-Colombia), and tested simultaneously under identical conditions as reported previously (Betancur-Galvis et al. 1999). Cell viability was evaluated by the MTT colorimetric technique (Mosmann 1983). Briefly, the supernatants were removed from the wells and $28 \mu \mathrm{l}$ of an MTT (Sigma) solution (2 $\mathrm{mg} / \mathrm{ml}$ in PBS) was added to each well. The plates were incubated for $1.5 \mathrm{~h}$ at $37^{\circ} \mathrm{C}$, and $130 \mu \mathrm{l}$ of DMSO was added to the wells to dissolve the MTT crystals. The plates were placed on a shaker for $15 \mathrm{~min}$ and the optical density was determined at $492 \mathrm{~nm}\left(\mathrm{OD}_{492}\right)$ on a multiwell spectrophotometer (Titertek Uniskan).

The $50 \%$ cytotoxic concentration $\left(\mathrm{CC}_{50}\right)$ of the test extract is defined as the concentration that reduce the $\mathrm{OD}_{492}$ of treated uninfected cells to $50 \%$ of that of untreated uninfected cells. The $50 \%$ antiviral effective concentration, i.e. $50 \%$ inhibitory concentration of the viral effect $\left(\mathrm{IC}_{50}\right)$ is expressed as the concentration that achieves $50 \%$ protection of treated infected cells from HSV-2 induced destruction. The percent protection is calculated as [(A-B)/C-B)]x100, where A, B and C are the $\mathrm{OD}_{492}$ of treated infected, untreated infected, and un- 
treated uninfected cells, respectively.

Cytotoxicity assay - Cell monolayers were trypsinized, washed with culture medium and plated in a 96-well flatbottomed plate with $5 \times 10^{3}$ cells per well for HeLa, HEp-2 and $\mathrm{CHO}$ cells and at $2 \times 10^{4}$ cells per well for Bon-Fib cells. After $24 \mathrm{~h}$ incubation, each diluted extract was added to the appropriate wells and the plates were incubated for a further $48 \mathrm{~h}$ at $37^{\circ} \mathrm{C}$ in a humidified incubator with $5 \%$ $\mathrm{CO}_{2}$. The supernatants were removed from the wells and cell viability was evaluated using the MTT technique as described above for the antiviral colorimetric assay. The results are obtained from triplicate assays with at least 5 extract concentrations. The percentage of cytotoxicity is calculated as $[(\mathrm{A}-\mathrm{B}) / \mathrm{A}] \mathrm{x} 100$, where $\mathrm{A}$ and $\mathrm{B}$ are the $\mathrm{OD}_{492}$ of untreated and of treated cells, respectively.

Data analysis - $\mathrm{CC}_{50}$ and $\mathrm{IC}_{50}$ for each compound were obtained from dose-effect-curves (not shown). The $\mathrm{CC}_{50}$ and $\mathrm{IC}_{50}$ are the average of four assays with 5 concentrations within the inhibitory range of the compounds. The therapeutic index (i.e. selective index) is defined as $\mathrm{CC}_{50} / \mathrm{IC}_{50}$.

\section{RESULTS AND DISCUSSION}

In the in vitro antiviral screening program we routinely use 2 methods of microculture assays for the evaluation of extracts of natural products with possible antiviral activity. One of these methods is EPTT (Vlietinck et al. 1995) and the other is a bioassay based on the metabolic reduction of MTT (Mosmann 1983, Denizot \& Lang 1986, Betancur-Galvis et al. 1999), so as to evaluate both the antiviral and antitumour activity. The selection of the $E u$ phorbia genus plant species for the present study was mainly based on the common use of these species for the treatment of various diseases, as indicated by traditional Colombian healers (Garcia-Barriga 1974, Perez 1975, Vasquez 1982, Piñeros et al. 1992).

The in vitro antitumour and antiviral activity of petroleum ether, dichloromethane, ethanol, water-methanol and water of 47 extracts from ten Euphorbia species has been estimated. A preliminary evaluation of the potential biological activities of all these extracts was carried out using the EPTT method, in which the cytotoxic activity and the antiviral effect were simultaneously evaluated (Table I). In this first step of the antiherpetic screening program, we evaluated the protection achieved by the extracts on HSV-2 induced cell destruction, and determined the reduction in cytopathic effect or the RF of the virus titer by means of EPTT. Vlietinck et al. (1995) have reported that only extracts with RFs of the virus titer of $>1 \times 10^{3}$ show relevant antiviral activity. As seen in Table I, the species showing the highest RF values at the maximal nontoxic dose were E. tirucalli and E. cotinifolia with values for water-methanol extracts of $10^{3}$ and $10^{4}$ respectively, indicating a strong activity against HSV-2. The ethanolic extracts of E. cestrifolia and E. tirucalli and dichloromethane extract of $E$. cotinifolia were moderately antiviral with RF values of $10^{2}$. The extracts of E. heterophyla, E. cyatophora and Euphorbia sp. were slightly active with RF values of $10^{1}$. In summary, out of 47 crude extracts corresponding to 10 different plant species of the genus Euphorbia, 5 extracts $(11 \%)$ representing 3 plant species $(30 \%)$ exhibited activity against HSV-2 (Table I).

The extracts with RF values of $1 \times 10^{2}$ to $1 \times 10^{4}$ were selected to be evaluated by the antiviral MTT colorimetric technique. Furthermore in some extracts the nontoxic concentration required to obtain the largest reduction of viral titer was close to the cytotoxic concentration needed to detach $100 \%$ of the cell monolayer $\left(\mathrm{CC}_{100}\right)$, revealing that their antiviral activity was due to their cytotoxicity. To clarify this aspect, it was necessary to calculate a selective index (i.e. therapeutic index) for each compound with antiviral activity to determine which extract had the best activity (i.e. highest therapeutic index). The in vitro therapeutic index was calculated using the $\mathrm{CC}_{50}$ for cell growth and the $\mathrm{IC}_{50}$, which were obtained by the MTT method.

As can be seen in Table II, the dichloromethane extract of E. cotinifolia and ethanol extract of E. tirucalli showed therapeutic index values of 4.08 and 3.46 respectively. Water-methanol extracts of $E$. cotinifolia and $E$. tirucalli showed the highest therapeutic index. The therapeutic index of these extracts did not have an exact value (>9.56 and $>7.13$ respectively); indeed, their $\mathrm{CC}_{50}$ values were not determined, because they had a value $>1000 \mu \mathrm{g} /$ $\mathrm{ml}$, in other words they were not cytotoxic. Comparing $\mathrm{IC}_{50}$ and therapeutic index values for Acyclovir (Wiltink \& Janknegt 1991) with the values for the E. cotinifolia and E. tirucalli water-methanol extracts, it can be concluded that these extracts have an acceptable antiviral activity. For this reason the E. cotinifolia and E. tirucalli species are good candidates for further activity-monitored fractionation to identify their active principles.

Table I also shows the cytotoxic effects of crude extracts tested on Vero cells. Six out of 47 extracts (13\%) representing 4 out of 10 plant species $(40 \%)$, detached $100 \%$ of the cell monolayer $\left(\mathrm{CC}_{100}\right)$ at concentrations of $50 \mu \mathrm{g} / \mathrm{ml}$; this concentration was the lowest observed in this assay, generally corresponding to the dichloromethane extracts of E. graminea, E. cotinifolia, E. cf. cotinifolia and Euphorbia sp. These active extracts were further tested for their cytotoxicity against several tumor cell lines using the MTT technique (Table III). The dichloromethane leaf extract of E. cotinifolia was the most toxic on the $\mathrm{HEp}-2$ tumor cell line and $\mathrm{CHO}$ cell line with a $\mathrm{CC}_{50}$ of 35.1 and $18.1 \mu \mathrm{g} / \mathrm{ml}$ respectively, but only if the extract had been obtained using a soxhlet extracter. When comparing the cytotoxicity of the dichloromethane leaf extract of $E$. cotinifolia with root hexanic extract of Rollinia membranacea, of the family Annonaceae, which is well known for its antitumor activity (Table III), it can be concluded that the former extract is a good candidate for further studies of activity-monitored fractionation to identify antitumour active principles.

The EPTT method is used by various investigators who have evaluated the antiviral activity of a large number of plants with precedents in traditional practices of folk medicine, and in several cases the specific indication claimed by traditional healers has been confirmed by antiinfective screening (Vlietinck et al. 1995, Unander et al. 1995, Tona et al 1999). Vlietinck et al. (1995) have reported the antiviral activity of certain species of the genus $E u$ phorbia and have identified 3-methoxyflavones as the 
active principles. To date, seven compounds with antiviral activity derived from 3-methylethers of quercetin and kaempferol have been isolated from $E$. grantii (Vlietinck et al. 1986, Van Hoof et al. 1984). Here we show that the best antiherpetic activities are present in E. cotinifolia and $E$. tirucalli. In this case, the fresh green material of either plant was percolated with aqueous alcoholic sol- vents, a methodology identical to that used by Colombian healers (Garcia-Barriga 1974, Perez 1975, Vasquez 1982, Piñeros et al. 1992).

The latex of species of the Euphorbia genus has also been used by tribes from the Colombian Amazonia both as fish poisons and arrow poisons to kill large animals (Garcia-Barriga 1974, Perez 1975, Vasquez 1982, Piñeros

TABLE I

Cytotoxicity and anti-HSV-2 activity of Euphorbia extracts on Vero Cells determined by the end-point titration technique

\begin{tabular}{|c|c|c|c|c|c|}
\hline Species & Plant tissue & $\begin{array}{l}\text { Extraction } \\
\text { medium }\end{array}$ & $\begin{array}{c}\mathrm{CC}_{100} \\
(\mu \mathrm{g} / \mathrm{ml})^{a}\end{array}$ & $\begin{array}{l}\text { Viral reduction } \\
\quad \text { factor } b\end{array}$ & $\begin{array}{c}\text { Antiviral } \\
\text { activity }(\mathrm{mg} / \mathrm{ml})^{c}\end{array}$ \\
\hline \multirow[t]{8}{*}{ E. heterophyla } & Stem & Petroleum ether & $>200$ & 1 & - \\
\hline & & Dichloromethane & 200 & $10^{1}$ & 100 \\
\hline & & Ethanol & 200 & 1 & - \\
\hline & & Water & $>200$ & 1 & - \\
\hline & Leaf & Petroleum ether & $>200$ & 1 & - \\
\hline & & Dichloromethane & 200 & $10^{1}$ & 100 \\
\hline & & Ethanol & 200 & $10^{1}$ & 100 \\
\hline & & Water & $>200$ & 1 & - \\
\hline \multirow[t]{4}{*}{ E. cyatophora } & Leaf/Stem & Petroleum ether & $>200$ & 1 & - \\
\hline & & Dichloromethane & 100 & 1 & - \\
\hline & & Ethanol & 100 & 1 & - \\
\hline & & Water & $>200$ & $10^{1}$ & 100 \\
\hline \multirow[t]{3}{*}{ E. graminea } & Leaf/Stem & Petroleum ether & $>200$ & - & - \\
\hline & & Dichloromethane & 50 & - & - \\
\hline & & Ethanol & $>200$ & $10^{1}$ & 200 \\
\hline \multirow[t]{4}{*}{ E. tirucalli } & Stem & Petroleum ether & 200 & $10^{1}$ & 100 \\
\hline & & Dichloromethane & 200 & $10^{1}$ & 100 \\
\hline & & Ethanol & $>200$ & $10^{2}$ & 100 \\
\hline & Leaf/Stem & Water-methanol & $>400$ & $10^{3}$ & 300 \\
\hline \multirow[t]{8}{*}{ E. cotinifolia } & Stem & Petroleum ether & 200 & 1 & - \\
\hline & & Dichloromethane & 100 & 1 & - \\
\hline & & Ethanol & 200 & $10^{1}$ & 100 \\
\hline & Leaf & Petroleum ether & 200 & 1 & - \\
\hline & & Dichloromethane & 200 & $10^{2}$ & 100 \\
\hline & & Dichloromethane $^{d}$ & 50 & 1 & - \\
\hline & & Ethanol & $>200$ & 1 & - \\
\hline & Leaf/Stem & Water-methanol & $>400$ & $10^{4}$ & 200 \\
\hline \multirow[t]{6}{*}{ E. arenaria } & Stem & Petroleum ether & 200 & 1 & - \\
\hline & & Dichoromethane & 100 & 1 & - \\
\hline & & Ethanol & $>200$ & 1 & - \\
\hline & Leaf & Petroleum ether & 200 & 1 & - \\
\hline & & Dichoromethane & 200 & 1 & - \\
\hline & & Ethanol & $>200$ & 1 & - \\
\hline \multirow[t]{6}{*}{ E. cestrifolia } & Stem & Petroleum ether & 200 & 1 & - \\
\hline & & Dichoromethane & 100 & 1 & - \\
\hline & & Ethanol & $>400$ & $10^{2}$ & 200 \\
\hline & Leaf & Petroleum ether & $>200$ & 1 & - \\
\hline & & Dichoromethane & $>200$ & $10^{1}$ & 200 \\
\hline & & Ethanol & 200 & 1 & - \\
\hline E. pulcherrima & Leaf/Stem & Water-methanol & $>400$ & 1 & - \\
\hline \multirow[t]{3}{*}{ E. cf. cotinifolia } & Leaf/Stem & Petroleum ether & 150 & - & - \\
\hline & & Dichoromethane & 50 & - & - \\
\hline & & Ethanol & 50 & - & - \\
\hline \multirow[t]{4}{*}{ Euphorbia. sp. } & Leaf/Stem & Petroleum ether & 200 & - & - \\
\hline & & Dichoromethane & 50 & $10^{1}$ & 25 \\
\hline & & Ethanol & 50 & - & - \\
\hline & & Water & 200 & $10^{1}$ & 100 \\
\hline Acyclovir & & & $>600$ & $10^{4}$ & 6.0 \\
\hline
\end{tabular}

$a$ : minimal toxic dose that detached $100 \%$ of the cell monolayer; $b$ : ratio of the virus titer in the absence over virus titer in the presence of the tested extract; $c$ : maximal nontoxic dose that showed the highest viral reduction factor; $d$ : extract obtained using a soxhlet extracter. 
TABLE II

Anti-HSV-2 activity of Euphorbia extracts on Vero Cells determined by the MTT method

\begin{tabular}{|c|c|c|c|c|c|}
\hline Species & Plant tissue & $\begin{array}{l}\text { Extraction } \\
\text { medium }\end{array}$ & $\mathrm{CC}_{50}(\mathrm{mg} / \mathrm{ml})^{a}$ & $\mathrm{IC}_{50}(\mathrm{mg} / \mathrm{ml})^{b}$ & $\begin{array}{c}\text { Therapeutic } \\
\text { index }\end{array}$ \\
\hline \multirow{3}{*}{ E. cotinifolia } & Leaf & Dichoromethane & 150.3 & 36.8 & 4.08 \\
\hline & Stem & Ethanol & 120.5 & 75.6 & 1.59 \\
\hline & Leaf/Stem & Water-methanol & $>1000$ & 104.6 & $>9.56$ \\
\hline \multirow{2}{*}{ E. cestrifolia } & Leaf & Dichoromethane & 169.2 & 59.8 & 2.83 \\
\hline & Stem & Ethanol & 225.3 & 160.1 & 1.41 \\
\hline \multirow[t]{2}{*}{ E. tirucalli } & Stem & Ethanol & 222.4 & 64.3 & 3.46 \\
\hline & Leaf/Stem & Water-methanol & $>1000$ & 140.2 & $>7.13$ \\
\hline Acyclovir & & & $9.1 \times 10^{4}$ & 2.8 & $31.6 \times 10^{3}$ \\
\hline
\end{tabular}

$a: 50 \%$ cytotoxic concentration; $b: 50 \%$ inhibitory concentration of the viral effect; $c$ : therapeutic index is defined as $\mathrm{CC}_{50}$ over IC $_{50}$.

TABLE III

Cytotoxic activity of Euphorbia extracts determined by the MTT technique

\begin{tabular}{|c|c|c|c|c|c|c|}
\hline \multirow[t]{2}{*}{ Species } & \multirow[t]{2}{*}{ Plant tissue } & \multirow{2}{*}{$\begin{array}{l}\text { Extraction } \\
\text { medium }\end{array}$} & HEp-2 & HeLa & $\mathrm{CHO}$ & Bon-Fib \\
\hline & & & \multicolumn{4}{|c|}{$\mathrm{CC}_{50}(\mu \mathrm{g} / \mathrm{ml})^{a}$} \\
\hline \multirow[t]{3}{*}{ E. cotinifolia } & Stem & Dichoromethane & 88.1 & 102.4 & 116.8 & 135.5 \\
\hline & Leaf & Dichoromethane & 249.5 & 212.5 & 211.0 & 295.1 \\
\hline & Leaf $b$ & Dichoromethane & 35.1 & N.D & 18.1 & 45.7 \\
\hline E. arenaria & Stem & Dichoromethane & 170.9 & 74.6 & 85.8 & 250.0 \\
\hline E. cestrifolia & Stem & Dichoromethane & 82.5 & 92.8 & 97.1 & 96.0 \\
\hline Euphorbia sp. & Leaf/Stem & Ethanol & 732.3 & 599.2 & 429.7 & 1126.0 \\
\hline E. cf. cotinifolia & Leaf/Stem & Dichoromethane & 282.7 & 224.4 & 178.2 & 316.3 \\
\hline R. membranacea ${ }^{c}$ & Root & Hexane & 2.22 & N.D & N.D & N.D \\
\hline
\end{tabular}

$a: 50 \%$ cytotoxic concentration; $b$ : extract obtained by extraction with soxhlet extracter; $c$ : positive control; N.D: not determinated; R: Rollinia

et al. 1992). The poison causes partial paralysis of the animals, and it has been suggested that this intoxication may be related to inhibition of the respiratory chain (Noack et al. 1980). Moreover, Falsone et al. (1982) have isolated a biologically active diterpene, which inhibits the NADH oxidase system of the mammalian mitochondrial respiratory chain. Research on inhibitors of the respiratory chain has revealed the existence of compounds with a high potential for basic biomedical research as possible antitumour agents (Degli Esposti et al. 1994, Zafra-Polo et al. 1996). Indeed, the bis-tetrahydrofuran acetogenin membrarollin isolated from $R$. membranacea, appears to be a very potent inhibitor of the NADH oxidase activity (Degli Esposti et al. 1994, Zafra-Polo et al. 1996). For this reason, the cytotoxic activity of the species $R$. membranacea has served here as a positive control (Betancur-Galvis et al. 1999) in experiments aimed at finding the antitumour potential of our extracts.

\section{ACKNOWLEDGMENTS}

To Dr Gloria Inés Sánchez (Group Infection and Cancer, Universidad de Antioquia) for help with manuscript critical reading and Carmen Beatriz Zuluaga for comments and suggestions. To the Group of Immunovirology - Biogénesis, for collaboration.

\section{REFERENCES}

Baker JT, Borris RP, Carte B, Cordell GA, Soejarto DD, Cragg GM, Gupta MP, Iwu MM, Madulid DR, Tyler VE 1995. Natural product drug discovery and development: new perspectives on international collaboration. J Nat Prod 58: 1325-1357.

Bernal HY, Correa JE 1990. Especies Vegetales Promisorias de los Países del Convenio Andrés Bello, Tomo VII, Secretaria Ejecutiva del Convenio Andrés Bello, Talleres de Editora Guadalupe Ltda., Bogotá, 480 pp.

Betancur-Galvis LA, Saez J, Granados H, Salazar A, Ossa JE 1999. Antitumor and antiviral activity of Colombian medicinal plant extracts. Mem Inst Oswaldo Cruz 94: 531535.

Carmichael J, DeGraff WG, Gazdar AF, Minna JD, Mitchell JB 1987. Evaluation of tetrazolium-based semiautomated colorimetric assay: assessment of chemosensitivity testing. Cancer Res 47: 936-942.

Cordell GA 1995. Changing strategies in natural products chemistry. Phytochemistry 40: 1585-1612.

Degli Esposti M, Ghelli A, Ratta M, Cortés D, Estornell E 1994. Natural substances (acetogenins) from the family Annonaceae are powerful inhibitors of mitocondrial NADH dehydrogenase (complex I). Biochem J 301: 161-167.

Denizot F, Lang R 1986. Rapid colorimetric assay for cell grow and survival modifications to the tetrazolium dye proce- 
dure giving improved sensitivity and reliability. J Immunol Meth 89: 271-277.

Falsone G, Crea AE, Noack EA 1982. Constituents of Euphorbiaceae, 7. 20-Deoxyingenol Monoesters and ingenol diesters from Euphorbia biglandulosa Desf. Arch Pharm (Weinheim) 12: 1026-1032.

Fatope MO, Zeng L, Ohayaga JE, Shi G, McLaughlin JL 1996. Selectively cytotoxic diterpenes from Euphorbia poisonii. J Med Chem 39: 1005-1008.

Garcia-Barriga H 1974. Flora Medicinal de Colombia. Botánica Médica, 2da ed., Universidad Nacional de Colombia, Talleres Editoriales de la Imprenta Nacional, Santa fé de Bogotá, $562 \mathrm{pp}$

Kusumoto IT, Nakabayashi T, Kida H, Miyashiro H, Hattori M, Namba T, Shimotohno K 1995. Screening of various plant extracts used in ayurvedic medicine for inhibitory effects on human immunodeficiency virus type 1(HIV-1) protease. Phytotherapy Res 9: 180-184.

Itokawa H, Ichihara Y, Watanabe K, Takeya K 1989. An antitumor principle from Euphorbia lathyris. Planta Med 55: 271-272.

Lorenz RJ, Bögel K 1973. Laboratory techniques in rabies. In MM Kaplan, H Koprowski (eds), Laboratory Techniques in Virology, World Health Organization, Geneva, 321 pp.

Mosmann T 1983. Rapid colorimetric assay for cellular grow and survival: application to proliferation and cytotoxicity assays. J Immunol Meth 65: 55-63.

Ninomiya Y, Shimma N, Ishitsuka H 1990. Comparative studies on the antirhinovirus activity and the mode action of the rhinovirus capsid binding agents chalcone amides. Antiviral Res 13: 61-74.

Noack EA, Crea AE, Falsone G 1980. Inhibition of mitochondrial oxidative phosporylation by 4-deoxyphorbol triester, a poisonous constituent of the latex of Euphorbia biglandulosa Desf. Toxicon 18: 165-174.

Pérez E 1975. Plantas Medicinales y Venenosas De Colombia. Estudio Botánico, Étnico, Farmacéutico, Veterinario y Forence, Hernan Salazar, Medellín, 186 pp.

Piñeros J, Garcia-Barriga H, Irequi A, Prias E, Perdomo C, Pueta HF 1992. Plantas Medicinales, Compendio de Farmacología Vegetal, 2da ed., Escuela de Medicina Juan N. Corpas, Fondo Editorial Universitario, Santa Fé de Bogotá, 211 pp.
Rubinstein LV, Shoemake RH, Paull KD, Simon RM, Tosini S, Skehan P, Scudiero DA, Monks A, Boy MR 1990. Comparison of in vitro anticancer-drug-screening data generated with a tetrazolium assay versus a protein assay against a diverse panel human tumor cell lines. J Nat Cancer Inst 82: 1113-1118.

Tona L, Kambu K, Mesia K, Cimanga K, Apers S, De Bruyne T, Pieters L, Totte J, Vlietinck AJ 1999. Biological screening of traditional preparations from some medicinal plants used as antidiarrhoeal in Kinshasa, Congo. Phytomedicine 6: 59-66.

Unander DW, Webster GL, Blumberg BS 1995. Usage and bioassays in Phyllanthus (Euphorbiaceae). IV. Clustering of antiviral uses and other effects. J Ethnopharmacol 45: 118.

Van Hoof L, Vanden Berghe DA, Hatfield GM, Vlietinck AJ 1984. Plant antiviral agents. V. 3-methoxyflavones as potent inhibitors of viral induced block of cell synthesis. Planta Med 50: 513-517.

Vasquez ML 1982. Euphorbia lanthyris. Plantas y Frutas Medicinales de Colombia y America, Editorial Climent, CaliColombia, $245 \mathrm{pp}$.

Vlietinck AJ, Van Hoof L, Totté J, Lasure A, Vanden Berghe D, Rwangabo PC, Mvukiyumwami J 1995. Screening of hundred Rwandese medicinal plants for antimicrobial and antiviral properties. J Ethnopharmacol 46: 31-47.

Vlietinck AJ, Vanden Berghe DA, Van Hoof LM, Vrijsen R, Boeye A 1986. Antiviral activity of 3-methoxyflavones. Prog Clin Biol Res 213: 537-540.

Weislow OW, Kiser R, Fine D, Bader J, Shoemaker RH, Boyd MR 1989. New soluble-formazan assay forHIV-1 cytopathic effects: application to high-flux screening of synthetic and natural products for AIDS-antiviral activity. $J$ Natl Cancer Inst 81: 577-586.

Wiltink EHH, Janknegt R 1991. Antiviral drugs. Pharmaceutisch Weekblad Scientific Ediction 13: 58-68.

Wu TS, Lin YM, Haruna M, Pan DJ, Shingu T, Chen YP, Hsu HY, Nakano T, Lee KH 1991. Antitumor agents, 119. Kansuiphorins A and B, two novel antileukemic diterpene esters from Euphorbia kansui. J Nat Prod 54: 823-829.

Zafra-Polo MC, Gonzáles MC, Estornell E, Sahpaz S, Cortés D 1996. Acetogenins from Annonaceae, inhibitor of mitocondrial complex I. Phytochemistry 42: 253-271. 